\title{
Mechanisms of phosphate solubilisation associated with some rhizobacteria in floodplains, as exemplified by the Okavango Region of Seronga, Botswana
}

\author{
Tabo Mubyana-John, Lawrence Tarupiwa, Wellington R. L. Masamba \& Susan \\ Ringrose
}

\begin{abstract}
Soil phosphorus may form insoluble complexes with some basic and acid cations and become unavailable to plants thus limiting plant growth. Both plants and microorganisms employ different mechanisms to make this phosphorus available to them. A study to isolate and assess phosphate solubilising ability of bacteria in the rhizosphere of grasses from the Seronga floodplains in the Okavango Delta, Botswana was conducted. Tentative phosphate solubilising bacteria were isolated from the rhizosphere and rhizoplane of 20 grasses and shrubs from the floodplains. Out of the many isolates, ten that showed maximum solubilising ability on different phosphate mineral agar were selected and studied further. The solubilisation ability was tested on different agar media containing $\mathrm{P}$ in possible soil phosphate complexes i.e., $\mathrm{KH}_{2} \mathrm{PO}_{4}, \mathrm{Mg}_{3}\left(\mathrm{PO}_{4}\right)_{2}, \mathrm{Ca}_{3}\left(\mathrm{PO}_{4}\right)_{2}$ using zones of phosphate clearance as a solubilisation indicator. The isolates were able to solubilise complexed phosphate on agar media as shown by the zones of clearance. When the isolates were assayed for their phosphatase enzyme production ability in liquid media and quantified using a spectrophotometer, most showed the ability to produce phosphatase in the medium. Growth in liquid potassium phosphate medium also resulted in a significant drop in $\mathrm{pH}$ indicating acid production and lowering of $\mathrm{pH}$ as possible mechanisms of phosphate solubilisation. Among the modes of action of phosphate solubilisation tested was the isolates ability to produce organic acids in liquid media. Assaying for the presence of organic acids in the isolates' growth medium showed that they were able to produce a wide range of organic acids ranging from simple ones such as acetic acid to complex ones such as 3Hydroxy-2-methyl-3-phenylpropionic acid. This study shows that some Seronga grasses and shrubs harbour phosphate solubilising rhizobacteria which may achieve this by producing organic acids that lower the $\mathrm{pH}$ in rhizosphere of the plants. The lower $\mathrm{pH}$ in turn results in release of phosphates that were bound by basic cations thus making them plant available.
\end{abstract}

Keywords: Floodplain; grasses and shrubs; microbial organic acids; Okavango Delta; phosphatase enzyme; soils.

Os mecanismos de solubilização de fosfato associados com algumas rizobactérias em várzeas, como exemplificado na região de Seronga no Okavango, Botswana

Resumo: $\mathrm{O}$ fósforo do solo pode formar complexos insolúveis com alguns cátions básicos e ácidos e tornar-se indisponível para as plantas, limitando assim seu crescimento. Plantas e microorganismos utilizam diferentes mecanismos para tornar esse fósforo disponível. Um estudo para isolar e avaliar a capacidade de solubilização de fosfato de bactérias na rizosfera de gramíneas das várzeas Seronga, no delta do Okavango, Botswana, foi realizado. Bactérias de solubilizacão de fosfato experimentais foram isoladas da rizosfera e rizoplano de 20 gramíneas e arbustos das várzeas. Dessas, as dez que mostraram capacidade máxima de solubilização em diferentes meios de ágar de fosfato mineral foram selecionadas e estudadas mais a fundo. A capacidade de solubilizacãa foi testada em diferentes meios de ágar contendo $\mathrm{P}$ em possíveis complexos de fosfato do solo, ou seja, $\mathrm{KH}_{2} \mathrm{PO}_{4}$, $\mathrm{Mg}_{3}\left(\mathrm{PO}_{4}\right)_{2}, \mathrm{Ca}_{3}\left(\mathrm{PO}_{4}\right)_{2}$, utilizando zonas selecionadas de fosfato do solo como um indicador de solubilização. As bactérias isoladas foram capazes de solubilizar fosfato complexo em meios de ágar, como mostrado nas zonas selecionadas. Quando foram testadas com relação à sua capacidade de produção de enzima fosfatase em meio líquido e quantificadas usando um espectrofotômetro, a maioria mostrou capacidade de produzir fosfatase no meio. O crescimento em meio de fosfato de potássio líquido também resultou em uma redução significativa no $\mathrm{pH}$, indicando a produção de ácido e diminuicão do $\mathrm{pH}$ como possíveis mecanismos de solubilização de fosfato. Entre os modos de ação de solubilizacão de fosfato testados, estava a capacidade das bactérias isoladas em produzir ácidos orgânicos em meio líquido. Testes da presença de ácidos orgânicos no meio de crescimento das bactérias isoladas mostraram que elas foram capazes de produzir grande variedade de ácidos orgânicos que vão desde os mais simples, tal como o ácido acético, aos mais complexos, como o ácido 3-Hidroxi-2-metil-3fenilpropiônico. Este estudo mostra que algumas gramíneas de Seronga abrigam rizobactérias de solubilização de fosfato, que podem fazê-lo através da produção de ácidos orgânicos que reduzem o pH na rizosfera das plantas. O pH mais baixo, por sua vez, resulta em liberação de fosfatos que estavam ligados por cátions básicos tornando-os assim disponíveis para as plantas.

Palavras-chave: ácidos orgânicos microbianos; Delta Okavango; enzima fosfatase; gramíneas e carriços; solos; várzea.

Received: 12 December 2013 -Accepted: 31 December 2013

\section{Introduction}

Phosphorus (P) is an essential macronutrient required by both plants and microorganisms (Wild 1988). It is readily absorbed as $\mathrm{PO}_{4}^{-3}$. Although present in soil, its plant and microbial availability is limited and controlled by soil activity and the presence of certain cations. At low
$\mathrm{pH}, \quad \mathrm{PO}_{4}^{-3}$ forms insoluble complexes with aluminium (Al) and iron (Fe) cations, while at a higher $\mathrm{pH}$ above 7 , it is complexed by basic cations such as calcium (Ca), magnesium $(\mathrm{Mg})$ and potassium $(\mathrm{K})$ and forms insoluble apatites (Brady 1990). Apart from the inorganic form, organic $\mathrm{P}$ forms often associated with organic matter, nucleic acids and phytin are also present in soil but are not readily available for plant uptake (Paul \& Clark 1996). Organically bound phosphorus is not directly available to organisms because it cannot be absorbed into cells in this form (Vance et al. 2003). Soil phosphates can be made available either by plant roots or soil microorganisms through many possible 
mechanisms. These include secretion of organic acids, production of phosphatase enzymes and complexing agents and reduction of $\mathrm{pH}$ (Duponnois et al. 2005). The phosphatase group of enzymes which play a major role in mineralisation of organic P include phytase enzymes that catalyse the release of phosphate from phytin and nuclease enzymes that liberate phosphate from nucleic acids (Rodrigueze \& Fraga 1999). These enzymes are produced by up to $70-80 \%$ of the microbial population, including bacteria such as Bacillus, Serratia and Arthrobacter spp., and fungi such as Aspergillus, Penicillium, Rhizopus, and Cunninghamella spp. (Rodrigueze \& Fraga 1999, Mohammadi 2012). Therefore, phosphate solubilising soil microorganisms play an important part in correcting phosphorus deficiency in plants. Once $\mathrm{P}$ is mineralized or solubilised it can be taken up by plants, and converted to plant and microbial biomass (Paul 2007).

High pH soils, which may be recognised by an accumulation of salts on the soil surface, are common in Botswana due to low rainfall and high evapotranspiration rates. In some areas this has resulted in huge surface salt pans such as the Makgadikgadi, Kang and Khakhea salt pans (Nash et al. 2004, Ringrose et al. 2005, Lebogang et al. 2009). The dominant cations in these soils are $\mathrm{Ca}, \mathrm{Mg}$ and $\mathrm{K}$. However in very high $\mathrm{pH}$ regions such as Rakops and Mopipi, $\mathrm{Na}$ is the dominant cation. These basic cations can form insoluble complexes with phosphates $\left(\mathrm{KH}_{2} \mathrm{PO}_{4}, \mathrm{Mg}_{3}\left(\mathrm{PO}_{4}\right)_{2}, \mathrm{Ca}_{3}\left(\mathrm{PO}_{4}\right)_{2}\right)$ making the phosphates unavailable to plants. Sorghum (Sorghum bicolor (L) Moench), the staple cereal crop in Botswana is grown by subsistence farmers in Seronga and wherever possible even on marginal lands. Therefore, crop failure due to nutrient deficiencies is a common sight. In many cases, the struggling crops exhibit purpling of leaves, a typical symptom of phosphorus deficiency (Mengel \& Kirkby 1982). Chemical fertilizers are often unaffordable to subsistence farmers in Seronga and other rural areas; as such crop failure is a common trait. In the Okavango irrespective of the common crop failure exhibited by both grain and sweet sorghum both of which are members of the Family Gramineae, wild grasses along the floodplains grow well without any visible $P$ deficiency symptoms even with no addition of artificial fertilisers or manure. Since many plants especially grasses harbour plant growth promoting bacteria in their rhizosphere (Jakobsen et al. 2005), it was hypothesised that the Seronga grasses and shrubs harbour phosphate solubilizing rhizobacteria which probably aid the plants in acquiring phosphates. Isolation and further processing of these would offer a solution to phosphate deficiencies in cultivated crops. In this research, phosphate solubilising bacteria from grasses and shrubs in Seronga floodplains were isolated and characterised. The study also explored some of the possible mechanisms that the phosphate solubilising isolates may employ.

\section{Materials and Methods}

The rhizobacteria used in this study had been previously isolated from dominant grasses, and shrubs in the floodplains of Seronga in the Okavango Delta (Botswana, S $18.816^{\circ}$, E 22.415 ). The isolation which had been done on National Botanical Research Institute phosphate growth medium (NBRIP) (Nautiyal et al. 2000) containing calcium phosphate and amended with $15 \mathrm{~g} / \mathrm{L}$ agar and $0.125 \mathrm{~g}$ of cyclohexamide, yielded about 15 isolates capable of solubilizing the calcium phosphate. The isolates which showed a clear halo in the opaque media were regarded as having the potential to solubilise phosphates. These isolates were purified by streaking them onto sterile fresh NBRIP solid medium. Once purified, the isolates were then maintained on agar slants and plates containing sterile NBRIP (calcium phosphate) amended with $0.125 \mathrm{~g}$ of cyclohexamide. The purified isolates were then subjected to further selection. The selection was first done on NBRIP calcium phosphate agar and later on other media each containing a different phosphate complex that is found in Botswana soils.

\section{Selection of strains with high phosphate solubilisation ability}

Initial selection of the phosphate solubilising bacteria (PSB) was done on the calcium phosphate agar plates. This was carried out by inoculating the sterile medium with the isolates at the centre of an agar plate. The plates were sealed with parafilm to prevent dehydration and then incubated at $25{ }^{\circ} \mathrm{C}$ for 20 days. The zones of clearance (halo zones) and diameter of the colonies produced by the isolates were measured at 4 day intervals using a Vernier calliper. These measurements were used to calculate the solubilisation index of each isolate. The solubilisation index (SI) (Alam et al. 2002) was calculated using the formula:

The higher the solubilisation index, the $S I=\frac{(\text { Colony diameter }+ \text { Halo zone diameter })}{\text { Colony diameter }}$

higher the phosphate solubilising ability of the isolate. An analysis of variance (ANOVA) of the solubilisation indices from the different isolates was also carried out to compare the solubilisation ability of the different isolates.

Soil phosphates also form insoluble complexes with cations such as magnesium, iron and potassium that commonly occur in Botswana soil. It is important that an isolate intended to be used in phosphate solubilisation in the rhizosphere should be able to solubilise the different phosphate complexes. Thus, secondary selection of the isolates was based on their ability to solubilise phosphate compounds which commonly occur in Botswana soils. The NBRIP medium was used but the calcium phosphate was replaced with the other phosphates commonly occurring in Botswana soils. The phosphate complexes tested were: potassium dihydrogen phosphate $\left(\mathrm{KH}_{2} \mathrm{PO}_{4}\right), \quad$ magnesium phosphate $\left(\mathrm{Mg}_{3}\left(\mathrm{PO}_{4}\right)_{2}\right)$, iron phosphate $\left(\mathrm{Fe}_{3}\left(\mathrm{PO}_{4}\right)_{2}\right)$, and aluminium phosphate $\left(\mathrm{Al}\left(\mathrm{PO}_{4}\right)\right)$. Precautions were taken when preparing the media in order to ensure that the amount of phosphate $\left(\mathrm{PO}_{4}^{-3}\right)$ in each of the different media was the same. To make the different phosphate media, the phosphate equivalent in the isolation calcium phosphate medium was calculated and replaced with the equivalent phosphate in the complex. Only ten of the isolates were capable of solubilising all the phosphates tested and these were selected for further study.

\section{Characterization of the isolates.}

Morphological characterisation, Gram stain, shape, motility and carbon source utilisation, of the isolates were determined as described by Gerhardt et al. (1981). Biochemical identification involving API 20E microtube identification system were carried out and interpreted according to the API 20E analytical profile index (bioMerieux Inc. USA). 


\section{Assessment of mechanisms of phosphate solubilisation}

Possible modes of bacterial phosphate solubilisation investigated in this study were the ability to regulate $\mathrm{pH}$ in such a way that the $\mathrm{pH}$ falls in the phosphate solubilisation range $(\mathrm{pH}$ 6.5-7.0), production of the enzyme phosphatase and production of organic acids.

\section{Effect of the isolates on $\mathrm{pH}$ of growth liquid medium}

Each of the ten isolates was inoculated into replica $100 \mathrm{ml}$ sterile potassium phosphate broth and incubated at room temperature on a rotary shaker at $100 \mathrm{rpm}$ for 28 days. Control flasks consisted of un-inoculated broth. Every 7 days, $10 \mathrm{ml}$ of the growth medium were removed and the $\mathrm{pH}$ measured using an Accumet ${ }^{\circledR} /$ Fisher Scientific Model $50 \mathrm{pH}$ meter (London, UK) with a combination glass electrode.

\section{Phosphatase activity and ability of the isolates to produce organic acids in growth medium}

The phosphatase production ability of the isolates and their ability to produce organic acids was determined by growing the isolates in sterile calcium phosphate broth and then assayed for the presence of phosphatase and the different organic acids in the supernatant. Each isolate was inoculated into replica $100 \mathrm{ml}$ sterile potassium phosphate broth and incubated on a rotary shaker at $100 \mathrm{rpm}\left(25^{\circ} \mathrm{C}\right)$ for 7 days. Control flasks consisted of uninoculated broth. After 7 days on the shaker, the cultures were harvested from the media by centrifuging at $6000 \mathrm{rpm}$ for 10 minutes. The cells were discarded while the supernatants were used for the determination of phosphatase activity and organic acid in the growth medium.

For the determination of phosphatase activity of the isolates, the phosphatase activity in the supernatants was assayed using $p$-nitrophenylphosphate ( $p$-NPP) as substrate and then analysed spectrophotometrically. After centrifuging and removal of bacteria, the supernatant was transferred to clean tubes and then used to assay for phosphatase activity using $p$-nitrolphenyl phosphate solution buffered at $\mathrm{pH} 11$ (Tabatabai 1982). This procedure extracts the $p$-nitrophenol released by the phosphatase activity in the

Table 1. Source of the isolates and their effect on growth media pH. Means followed by the same letter in the same column are not significantly different from each other at $5 \%$.

\begin{tabular}{cccccc}
\hline Isolate & Plant source & Day 1 & Day 7 & Day 14 & Day 21 \\
\hline S1 & $\begin{array}{c}\text { Eulesine } \\
\text { africana }\end{array}$ & $6.54 \mathrm{a}$ & $5.92 \mathrm{ab}$ & $5.89 \mathrm{ab}$ & $5.81 \mathrm{a}$ \\
$\mathrm{S} 2$ & $\begin{array}{c}\text { Imperata } \\
\text { cylindrica }\end{array}$ & $6.54 \mathrm{a}$ & $6.12 \mathrm{~b}$ & $6.13 \mathrm{~b}$ & $5.91 \mathrm{a}$ \\
$\mathrm{S} 3$ & $\begin{array}{c}\text { Imperata } \\
\text { cylindrica }\end{array}$ & $6.54 \mathrm{a}$ & $5.97 \mathrm{a}$ & $5.94 \mathrm{~b}$ & $5.91 \mathrm{a}$ \\
$\mathrm{S} 4$ & $\begin{array}{c}\text { Sesbania } \\
\text { seban }\end{array}$ & $6.54 \mathrm{a}$ & $6.14 \mathrm{~b}$ & $5.52 \mathrm{a}$ & $6.07 \mathrm{ab}$ \\
$\mathrm{S} 5$ & $\begin{array}{c}\text { Panicum } \\
\text { maximum }\end{array}$ & $6.54 \mathrm{a}$ & $6.00 \mathrm{~b}$ & $5.89 \mathrm{ab}$ & $5.82 \mathrm{a}$ \\
$\mathrm{S} 6$ & $\begin{array}{c}\text { Cyperus sp } \\
\text { Cynodon }\end{array}$ & $6.54 \mathrm{a}$ & $5.94 \mathrm{ab}$ & $5.96 \mathrm{~b}$ & $5.93 \mathrm{a}$ \\
$\mathrm{S} 8$ & $\begin{array}{c}\text { Cyctylon } \\
\text { dan }\end{array}$ & $6.54 \mathrm{a}$ & $5.86 \mathrm{a}$ & $5.85 \mathrm{ab}$ & $5.82 \mathrm{a}$ \\
$\mathrm{S} 9$ & $\begin{array}{c}\text { Urochloa } \\
\text { decumbens } \\
\text { Urochloa }\end{array}$ & $6.54 \mathrm{a}$ & $6.02 \mathrm{ab}$ & $6.01 \mathrm{~b}$ & $5.89 \mathrm{a}$ \\
$\mathrm{S} 10$ & $\begin{array}{c}\text { trichophus } \\
\text { Control }\end{array}$ & $6.54 \mathrm{a}$ & $5.41 \mathrm{a}$ & $5.26 \mathrm{a}$ & $6.14 \mathrm{ab}$ \\
\hline
\end{tabular}

supernatant that develops a stable yellow colour. The yellow colour which is read on the spectrophotometer at $420 \mathrm{~nm}$ and used to estimate the phosphatase activity (Tabatabai 1982, Jones 1997). A standard curve was prepared by using $1 \mathrm{mM}$ solutions of $p$-nitrophenol in water. Concentrations of $0,1,2,3,4,5,7.5$ and $10 \mu \mathrm{m}$ were used to prepare the final standard curve that was used to determine the concentration of phosphatase in the supernatants.

Determination of organic acids in the supernatants was done using a procedure outlined by Suh (1997). Two millilitres of the supernatants were pipetted into clean $15 \mathrm{ml}$ centrifuge tubes. The $\mathrm{pH}$ of the supernatants was adjusted to less than 1 by adding $200 \mu \mathrm{l}$ of $6 \mathrm{M} \mathrm{HCl}$. This was followed by the addition of $1.5 \mathrm{~g}$ of $\mathrm{NaCl}$. The tubes were left overnight on a shaker set at $100 \mathrm{rpm}$. A $5 \mathrm{ml}$ aliquot of ethyl acetate was added and tubes were shaken for 10 minutes at $100 \mathrm{rpm}$. The tubes were centrifuged at $6000 \mathrm{rpm}$ for 10 minutes. Using a Pasteur pipette, the organic layer was transferred into a $20 \mathrm{ml}$ beaker. The beakers were left in a fume hood overnight to evaporate the solvent. The residue that remained in these beakers was dried in a desiccator with silica gel. Exactly $1 \mathrm{ml}$ of chlorotrimethylsilane was added into each beaker to dissolve the residue and then heated at $60{ }^{\circ} \mathrm{C}$ for 15 $\mathrm{min}$. After heating, a 2-ml aliquot of each sample was injected into the gas chromatography -mass spectrometer (GCMS) column with an autosampler to identify the organic acids that may be secreted by the isolates. The gas chromatography-mass spectrometer (GCMS) was used because it is non-selective and enables both high separation efficiency and structural specificity of organic acids

\section{Results}

Many bacteria were able to grow and show halo zones of clearance on NBRIP (calcium phosphate) agar, however, not all were able to grow on the medium when purified. The final selection was based on the ability to grow on the phosphate media containing common basic cations that could complex $\mathrm{PO}_{4}^{-3}$ in Botswana soils. Of the 15 isolates obtained from the rhizosphere of the grasslands of Seronga, only ten showed the ability to utilise the phosphate when tested on calcium, magnesium and potassium phosphate agar. Nine of the isolates were from grasses while one was from the leguminous shrub Sesbania spp. The isolates were coded $\mathrm{S} 1$ to $\mathrm{S} 10$. Successive transfers however only yielded nine isolates. Table 1 shows the plant sources from which the different isolates were obtained. Even if 24 different plant 
species had been sampled, not all yielded phosphate solubilising bacteria from their rhizospheres; many did not. Table 2 lists sampled grasses that did not yield any phosphate solubilising bacteria. Tentative studies show that all the isolates were Gram negative; motile, short and medium rods.

Table 2. List of sampled plants that did not yield phosphate solubilising bacteria.

Nr. Species name

1 Aristida meridionalis (Hackel) Clayton

Andropogon guyanus (Hackel)
Clayton

3 Cympogon excavatus (Hochst.) Stapf

4 Eragrostis inamoena K.Schum

5 Eragrostis lapula Nees

6 Eragrostis rigidor Pilger

7 Eragrostis superba Per.

8 Panicum colaratum $\mathrm{L}$.

9 Panicum repens $\mathrm{L}$.

10 Setaria sphacelata (Schumach.) Moss

11 Setaria verticilata (L.) Beauv

12 Sporobolus acinifolis Stapf

13 Sporobolus africanus (Poic.) Robyns Tournay

14 Sporobolus spicatus (Vahl) Kunth

15 Stipagrostis uniplumis (Lichtenst. ex Roemer \& Schultes) de Winter

16 Veteveria nigritiana (Benth.) Stapf.

The solubilisation ability was observed on solid agar plates as clear halo zones around the bacteria colonies. Figure 1 gives an example of the zone of clearance as depicted by the isolate S10 on NBRIP (calcium phosphate). Different isolates

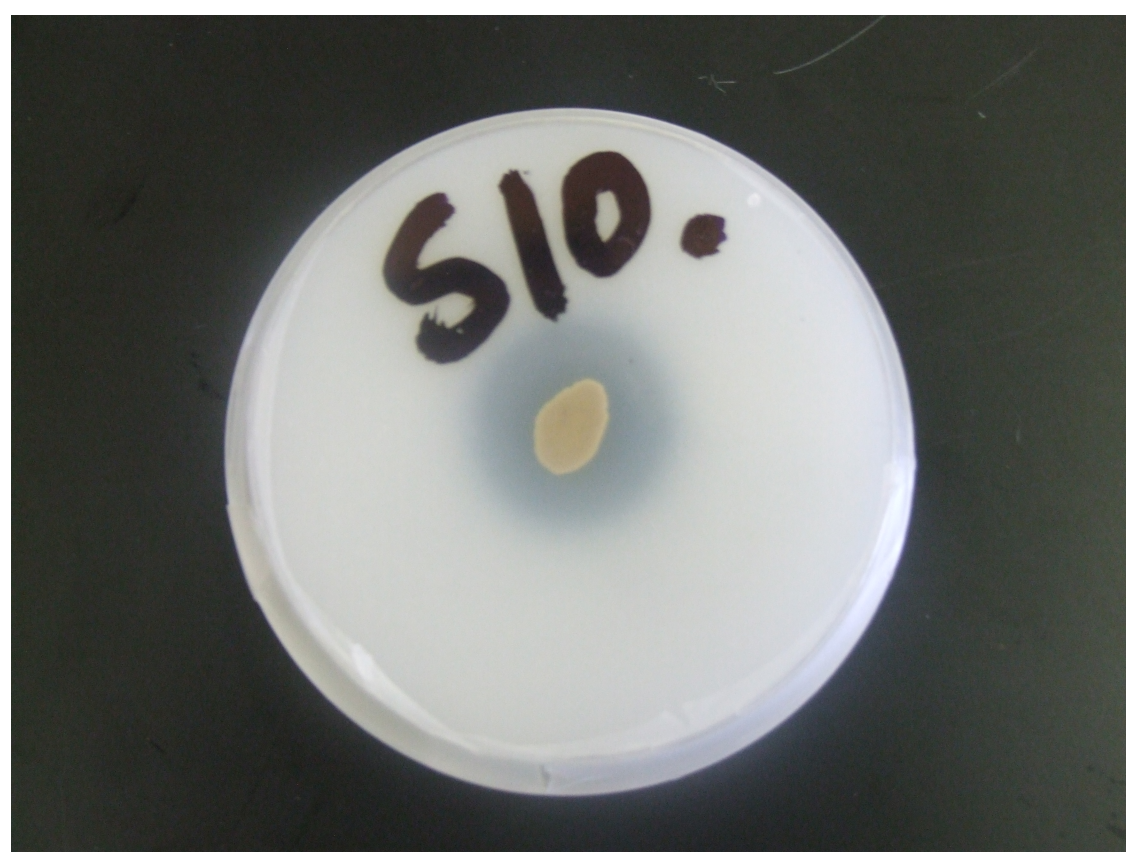

Fig. 1: Phosphate solubilising ability of isolate $\mathrm{S} 10$ on $-\mathrm{Ca}_{3}\left(\mathrm{PO}_{4}\right)_{2}$ medium shown by the halo zone of clearance around the colony.

showed different ability of solubilisation depending on the cation complexed with phosphate. As such the different isolates had different solubilisation indices on different media. None of the isolates showed the ability to solubilise phosphate bound by the acid cations tested i.e., iron and aluminium. Figure 2 shows the solubilisation indices of the different isolates on the solid phosphate media after 28 days of incubation.

\section{Effect of the isolates on growth media pH}

When grown on liquid phosphate medium the isolates showed the ability to lower the $\mathrm{pH}$ of the medium. Table 1 shows the effect of the isolates on the $\mathrm{pH}$ of the medium over a period of 21 days. During the 21 days incubation period, the $\mathrm{pH}$ of the media declined from 6.40 to as low as 5.81 in some of the isolates. Although the lowering of the $\mathrm{pH}$ was not always large in all the isolates, there were no $\mathrm{pH}$ media changes observed in the un-inoculated medium.

\section{Phosphatase activity of the isolates}

Figure 3 shows the phosphatase activity of the supernatant as measured by the $p$ nitrophenol content. All the isolates showed some phosphatase activity with isolate S9 significantly higher than the other isolates.

Analysis of the bacterial supernatant showed that these isolates produced many different organic acids during growth in liquid medium. Table 3 shows possible organic acids produced by the different isolates when grown in liquid culture medium as given by the GC-MS.

\section{Discussion}

Seronga floodplains contain grasses and shrubs that harbour phosphate solubilising bacteria in their rhizosphere as many bacteria were able to grow on (NBRIP) media (Table 1). Although many bacteria were isolated, due to the presence of oligophosphophiles and other phosphate scavengers, several transfers and testing on fresh media had to be made before pure phosphate solubilising bacterial colonies could be obtained. Their ability to solubilise phosphates on opaque media was observed as clear halo zones around the colonies (Fig. 1). In this study the purification only yielded ten isolates, one of which failed to solubilise the $\mathrm{PO}_{4}^{-3}$ after several transfers. Failure of this isolate to continue growing after successive transfers may be due to exhaustion of rare micronutrients, growth factors and vitamins which do not normally exist in the commercial medium but are often carried over from soil (Wollumn 1982, Warren et al. 2002). Irrespective of all the selected isolates' ability to solubilise $\mathrm{PO}_{4}^{-3}$ on all the basic cations tested i.e., $\mathrm{Ca}, \mathrm{Mg}$ and $\mathrm{K}$, none of the isolates tested were able to solubilise 


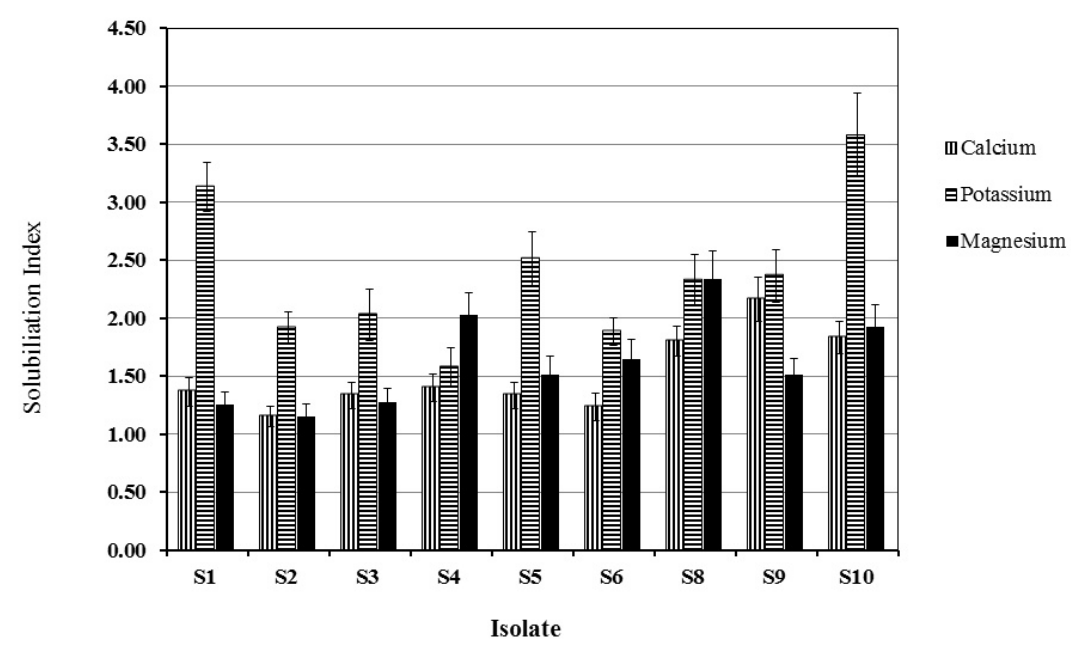

Fig. 2: Phosphate solubilising ability of the isolates on Calcium, Magnesium and Potassium phosphate media as indicated by solubilisation indices after 28 days. Error bars represent standard deviations.

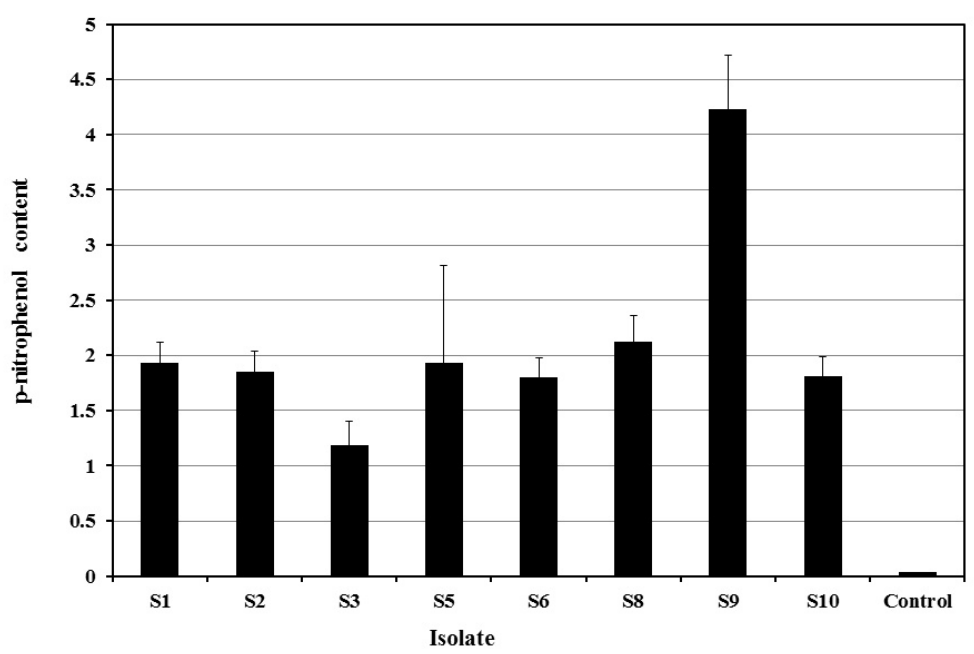

Fig. 3: Phosphatase activity ( $\left.\mu \mathrm{m} \mathrm{PO}_{4}^{-3} / \mathrm{L} / \mathrm{hr}\right)$ ) of the isolates as indicated by $p$ nitrolphenol content. Error bars represent standard deviations.

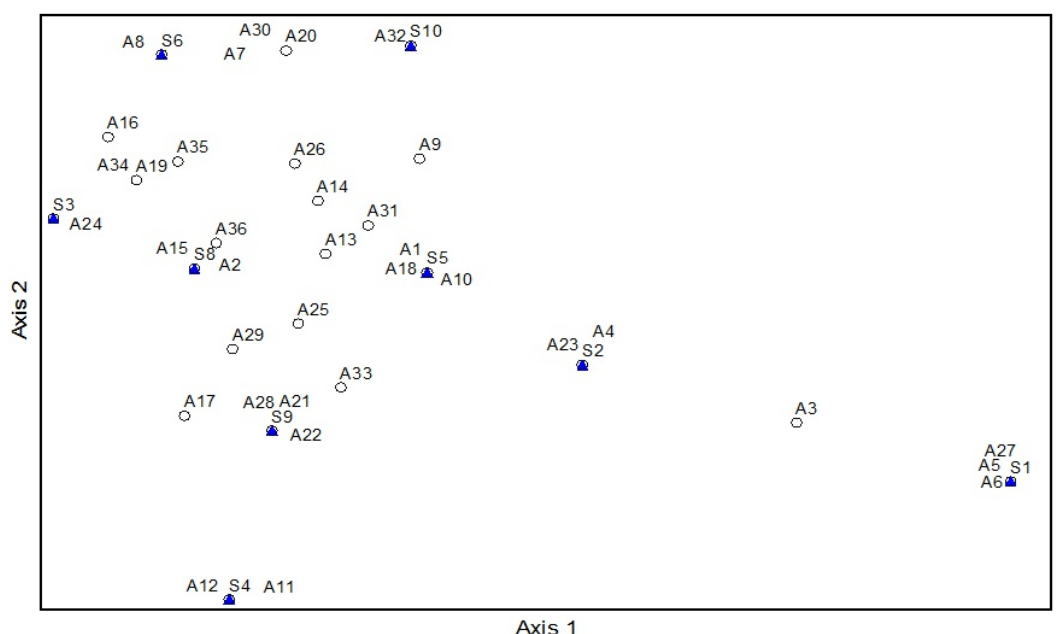

Fig. 4: Non-metric Multi-dimensional Scaling of isolates by compound run using Sorensen distance measure, 250 runs with real data. (PcOrd ver. 6.04, McCune and Mefford, 2011). S1-S10 = Isolates, A1-A37 = Compounds. phosphates on acid cations tested i.e., iron (Fe) and aluminium (Al) phosphate. Hence no clear halo zones were formed on media where the phosphate was in the form of iron phosphate or aluminium phosphate. Different isolates showed different solubilisation indices depending on the cation phosphate used (Fig. 2). These ranged from 3.5 in isolate $\mathrm{S} 10$ to 1.2 for S2. Of the different isolates tested S8 and S10 seemed to have the highest solubilisation indices and showed significantly larger halos than the other isolates on all the phosphate media tested. Since these isolates can solubilise phosphates complexed by $\mathrm{Ca}, \mathrm{K}$ and $\mathrm{Mg}$ they could be used in almost all Botswana soils as these are the dominant cations in these soils (Bonyongo and Mubyana 2004, Ringrose et al., 2005).

The isolates also showed the ability to lower $\mathrm{pH}$ of the liquid growth media (Table 1) indicating lowering of $\mathrm{pH}$ as a possible mechanism of making soil phosphate available. Although all the isolates showed the ability to lower $\mathrm{pH}$ of the growth medium, some were more effective than others as observed by the significantly lowering $\mathrm{pH}$ of $\mathrm{S} 1$ and $\mathrm{S} 8$ compared to $\mathrm{S} 4$ and $\mathrm{S} 10$ where the $\mathrm{pH}$ lowering was non-significant when compared to the control. Lowering of high $\mathrm{pH}$ in soil results in an increase in available $\mathrm{PO}_{4}^{-3}$ in the soil solution and therefore making it plant available (Brady 1990). This study indicates that although some isolates may use this mechanism, not all isolates may use $\mathrm{pH}$ lowering as a mechanism of making $\mathrm{PO}_{4}^{-3}$ available.

Some of the isolates' growth media showed a significant amount of phosphatase activity as indicated by the amount of $p$-nitrophenol produced (Fig. 3). The phosphatase activity of the medium ranged from as high as 4.01 in $\mathrm{S} 9$ to as low as $1.85 \mu \mathrm{mPO}_{4}^{-3} / \mathrm{L} / \mathrm{hr}$ in $\mathrm{S} 3$ (Fig. 3 ) indicating a significant difference in the enzyme production ability of the different isolates. This study is in accordance with Richardson (2000) who showed that some bacteria produce phosphatase enzymes in order to mineralise organic phosphates.

Gas chromatography-Mass spectrometry analysis of the growth medium showed that these isolates excrete up to 36 different acids as extra cellular metabolites in liquid media. These include simple ones such as acetic, formic, phosphoric, propionic acid and more complex and cyclic acids such as 2,2Biphenylylenephosphoric, Chloroaniline-5-sulfonic, trifluromethylbenzoic,
2-Fluoro-5$2-$ 
Table 3. Organic acids produced by the different isolates in growth media and their designation.

\begin{tabular}{|c|c|c|c|c|}
\hline Isolate & Name of organic acids found & Designation & Name of organic acids found & Designation \\
\hline \multirow[t]{2}{*}{$\overline{\mathrm{S1}}$} & a) 2-Chloroaniline-5-sulfonic acid & A5 & c) 2-trifluromethylbenzoic acid & A3 \\
\hline & b) 2-Fluoro-5-trifluromethylbenzoic acid & A6 & d) Isophthalic acid & A27 \\
\hline \multirow[t]{3}{*}{ S2 } & a) 2-Trifluromethylbenzoic acid & A3 & d) Phthalic acid & A31 \\
\hline & b) 2,2-Biphenylylenephosphoric acid & A4 & e) Propanoic acid & A33 \\
\hline & c) Ethylbenzoic acid & A23 & & \\
\hline \multirow[t]{3}{*}{ S3 } & a) Butenoic acid & $\mathrm{A} 17$ & d) Butenedioic acid & A16 \\
\hline & b) Carbamic acid & A19 & e) Phthalic acid & A31 \\
\hline & c) Formic acid & A24 & f) Propenoic acid & A34 \\
\hline \multirow[t]{2}{*}{ S4 } & a) Azetidinecarboxylic acid & A11 & c) Butenoic acid & A17 \\
\hline & b) Benzeneacetic acid & $\mathrm{A} 12$ & d) Propanoic acid & A33 \\
\hline \multirow[t]{5}{*}{ S5 } & a) (Benzo(b)thien-6-yl)acetic acid & A1 & f) Butynoic acid & A18 \\
\hline & b) Acetic acid & A9 & g) Hexadecanoic acid & A25 \\
\hline & c) Aminosalicylic acid & A10 & h) Hexanedioic acid & A26 \\
\hline & d) Benzoic acid & A13 & i) Octadecanoic acid & A31 \\
\hline & e) Butanedioic acid & A14 & j) Propanoic acid & A33 \\
\hline \multirow[t]{5}{*}{ S6 } & a) 3-Hydroxy-2-methyl-3-phenylpropionic acid & A7 & e) Hexadecanoic acid & A25 \\
\hline & b) Benzoic acid & $\mathrm{A} 13$ & f) Octadecanoic acid & A29 \\
\hline & c) Butanoic acid & A15 & g) Propanoic acid & A33 \\
\hline & d) Carbamic acid & A19 & h) Propenoic acid & A34 \\
\hline & & & i) Terephthalic acid & A35 \\
\hline \multirow[t]{5}{*}{ S8 } & a) 1-Adamantanecarboxylic acid & A2 & f) Hexadecanoic acid & A26 \\
\hline & b) 5- Isoxazolecarboxylic acid & A8 & g) Octadecanoic acid & A29 \\
\hline & c) Benzoic acid & $\mathrm{A} 13$ & h) Phthalic acid & A31 \\
\hline & d) Butenedioic acid & A16 & i) Propanoic acid & A33 \\
\hline & e) Carbamic acid & $\mathrm{A} 20$ & & \\
\hline \multirow[t]{5}{*}{ s9 } & a) Benzoic acid & A13 & f) Hexadecanoic acid & A25 \\
\hline & b) Butanedioic acid & $\mathrm{A} 14$ & g) Naphthoic acid & A28 \\
\hline & c) Butenoic acid & A17 & h) Octadecanoic acid & A29 \\
\hline & d) Cyanic acid & A21 & i) Propanoic acid & A33 \\
\hline & e) Ethaneperoxoic acid & A22 & j) Tetredecanoic acid & A36 \\
\hline \multirow[t]{4}{*}{ S10 } & a) Acetic acid & A9 & e) Phosphonic acid & A30 \\
\hline & b) Benzoic acid & $\mathrm{A} 13$ & f) Phthalic acid & A31 \\
\hline & c) Butanedioic acid & $\mathrm{A} 14$ & g) Propanedioic acid & A32 \\
\hline & d) Carbonic acid & A20 & & \\
\hline
\end{tabular}

trifluromethylbenzoic and 3-Hydroxy-2methyl-3phenylpropionic acid (Table 3). Non-metric Multidimensional Scaling (NMS) shows that the acids and isolates can be grouped into three categories (Fig. Fluoro-5-trifluromethylbenzoic acid) and 4). The first category has isolates S1 A27 (Isophthalic acid). The second group grouped together with A5 (2- has S2 associated with A4 (2,2Chloroaniline-5-sulfonic acid), A6 (2- Biphenylylenephosphoric acid) and A23 
(Ethylbenzoic acid). In the third group, S4 is associated with A11 (Azetidinecarboxylic acid) and A12 (Benzeneacetic acid). The final group, which is much larger than the other three contains the remaining isolates and acids. This study is in accordance with studies in other regions which have also shown bacterial production of organic acid as a possible mechanism by which some bacteria may solubilise insoluble inorganic phosphates in soil thus making them available to plants (Khan 2009). Although these phosphorus solubilising bacteria were isolated from the Seronga part of the Okavango region, it is highly likely that other floodplains such as in the Niger Delta and other African deltas with similar climatic conditions may harbour beneficial phosphorus solubilising bacteria which could serve as a solution to phosphate solubilisation in agricultural systems.

Overall, this study shows that some Seronga plants such as grasses and shrubs harbour phosphate solubilising bacteria in their rhizosphere. These rhizobacteria may play a role in solubilising soil phosphates thus making it plant available. This may be achieved by mechanisms such as lowering of $\mathrm{pH}$, production of organic acid and/or production of the phosphatase enzymes. The phosphate solubilising bacterial isolates can only be effective in high $\mathrm{pH}$ soils containing $\mathrm{Ca}, \mathrm{Mg}$ and $\mathrm{K}$ phosphates. They are highly likely to have no effect in soils where the phosphate is complexed by $\mathrm{Fe}$ or $\mathrm{Al}$.

\section{Acknowledgements}

The authors greatly appreciate The Future Okavango (Okavango Research InstituteGermany collaboration) for funding this project. They also greatly appreciate Dr. K. Sichilongo, Chemistry Department, University of Botswana for the Gas Chromatography-Mass Spectrometry work analysis of organic acids. The work was carried out under Permit No EWT 8/36/4 XVI (66) issued by the Botswana Ministry of Environment, Wildlife and Tourism.

\section{References}

Alam, I., Khali, S.A., Ayuba, N., Rashid, M. (2002): In vitro solubilisation of inorganic phosphate by phosphate solubilising microorganisms (PSM) from maize rhizosphere. - International Journal of Agriculture and Biology 4(4): 454-458.
Bonyongo, M.C., Mubyana, T. (2004): Soil nutrient status in vegetation communities of the Okavango Delta floodplains. South African Journal of Science 100: 337-340.

Brady, N.C., (1990): The Nature and Properties of Soils. 10th ed. - Macmillan Publishing Company New York.

Duponnois, R., Colombet, A., Hien, V., Thioulouse, J. (2005): The mycorrhizal fungus Glomus intraradices and rock phosphate amendment influence plant growth and microbial activity in the rhizosphere of Acacia holosericea. - Soil Biology and Biochemistry 37: 1460-1468. CrossRef

Gerhardt P., Murray R.G.E., Costilow R.N., Nester E.W., Wood W.D., Krieg N.R., Phillips B.G. (1981): Manual of Methods in General Bacteriology. - American Society for Microbiology Washington DC. Jakobsen, I., Leggett, M.E., Richardson, A.E. (2005): Rhizosphere microorganisms and plant phosphorus uptake. - In: Sims, J.T., Sharpley, A.N. [Eds.]: Phosphorus: Agriculture and the Environment. - American Society for Agronomy, Madison, WI.

Jones, R. D., (1997): Phosphorus cycling. - In: Hurst, J.C., Knudsen, G.R., Mclnerney, J.M., Stetzenbach L.D., Walter, M.V. [Eds.]: Manual of Environmental Microbiology. - American Society of Microbiology Press, Washington, D.C.

Khan, A. A. (2009): Phosphorus solubilising bacteria: Occurrence, mechanisms and their role in crop production. - Journal of Agricultural and Biological Sciences 1 (1): 48-58.

Lebogang, L., Taylor, J.E., Mubyana-John, T. (2009): A preliminary study of the fungi associated with salt pans in Botswana and their antimicrobial properties. Bioremediation, Biodiversity and Bioavailability 3(2): 61-71; Global Science books. MacMillan Publishing Company.

McCune, B., Mefford, M.J. (2011): PCORD. Multivariate Analysis of Ecological Data. Version 6.04. - MjM Software, Gleneden Beach, Oregon, U.S.A.

Mengel, K., Kirkby, E.A. (1982): Principles of plant nutrition. - International Potash Institute: Bern Switzerland.

Mohammadi, K. (2012): Phosphorus solubilizing bacteria: Occurrence, mechanisms and their role in crop production. - Resources and Environment 2(1): 80-85.

Nash, D.J., McLaren, S.J., Webb, J.A., (2004): Petrology, geochemistry and environmental significance of silcrete-calcrete intergrade deposits at Kang Pan and Tswane, Central Kalahari, Botswana. - Earth Surface. Processes and Landforms 29: 1559-1585. CrossRef

Nautiyal, C.S., Bhadauria, S., Kumar, K., Hind Lal, Mondal, R., Verma, D. (2000):
Stress induced phosphate solubilisation in bacteria isolated from alkaline soils. FEMS Microbiology Letters 182: 291-296. CrossRef

Paul, A.E. (2007): Soil microbiology, ecology and biochemistry. 3rd ed. USA: Elsevier Inc.

Paul, E.A., Clark, F.E. (1996): Soil microbiology and biochemistry. Academic Press.

Richardson, A. E. (2000): Prospects for using soil microorganisms to improve the acquisition of phosphorus by plants. Australian Journal of Plant Physiology 28: 897-906. CrossRef

Rodrigueze, H., Fraga, R. (1999): Phosphate solubilising bacteria and their role in plant growth promotion. Biotechnology Advances 17: 319-339. CrossRef

Ringrose, S., Huntsman-Mapila, P., Kampunzu, A.B., Downey W., StephanCoetzee, S., Vink, B., Matheson, W., Vanderpost, W.C. (2005): Sedimentological and geochemical evidence for palaeo-environmental change in the Makgadikgadi subbasin in relation to the MOZ rift depression, Botswana. - Palaeogeography, Palaeoclimatology, Palaeoecology 217: 265-287. CrossRef

Suh, J.W., (1997): GC-MS Determination of organic acids with solvent extraction after cation-exchange chromatography. - Clinical Chemistry 43(12): 2256-2261.

Tabatabai, M.A., (1982): Soil enzymes. -In: Page, A.L., Miller, R.H., Keeney, D.R. [Eds.]: Methods of Soil Analysis Part 2. Chemical and microbiological properties. - American Society of Agronomy, Madison: Wisconsin.

Vance, C. P., Uhde-Stone, C., Allan, D. L. (2003): Phosphorous acquisition and use: critical adaptations by plants for securing a non-renewable resource. New Phytologist 157: 423-447. CrossRef

Warren, A., Day, J.G, Brown, S. (2002): Cultivation of algae and protozoa. - In: Hurst, C.J., Crawford, R.L., Knudsen, G.R., Mclnerney, M.J., Stetzenbach, L.D., [Eds]: Manual of Environmental Microbiology (2nd Ed). - American Society of Microbiology Press, USA.

Wild, A. (1988): Russell's Soil Conditions and Plant Growth. - Longmans. London.

Wollum II, A.G., (1982): Cultural methods for soil microorganisms. -In: Page, A.L, Baker, D.E, Keeney, D.R., [Eds.]: Methods of Soil Analysis, Part 2. Chemical and microbiological properties. - American Society of Agronomy Inc. and Soil Science Society of America Inc. Madison USA. 


\section{Affiliations}

Tabo Mubyana-John

(MUBYANAT@mopipi.ub.bw),

Lawrence Tarupiwa

(1tarupiwa@yahoo.com)

Department of Biological Sciences

University Of Botswana

PO Box 0022

Gaborone, BOTSWANA

Wellington R. L Masamba

(wmasamba@ori.ub.bw)

Okavango Research Institute

University of Botswana

PO Box 285

Maun, BOTSWANA

Susan Ringrose

(sringrose66@gmail.com)

Independent Consultant

PO Box HA 65 HAK,

Maun, BOTSWANA 